\title{
ISSFAL 2014 Debate: It Is Time to Update Saturated Fat Recommendations
}

\author{
Joyce A. Nettleton ${ }^{\mathrm{a}}$ Philippe Legrand $^{\mathrm{b}}$ Ronald P. Mensink ${ }^{\mathrm{c}}$ \\ ${ }^{a}$ ScienceVoice Consulting, Denver, Colo., USA; ${ }^{b}$ Biochemistry and Human Nutrition, Agrocampus-INRA, European \\ University of Brittany, Rennes, France; ' $N$ UTRIM School for Nutrition Toxicology and Metabolism, Faculty of Health, \\ Medicine and Life Sciences, Maastricht University, Maastricht, The Netherlands
}

\author{
Key Words \\ Saturated fatty acids . Dietary recommendations $\cdot$ Dietary \\ fat and coronary heart disease
}

\begin{abstract}
This paper summarizes a debate on whether to update recommendations for the consumption of saturated fatty acids (SFA); this debate was held at the 11th congress of the International Society for the Study of Fatty Acids and Lipids in Stockholm, Sweden, June 28-July 2, 2014. Recommendations to reduce SFA intakes are based largely on the premise that high intakes of SFA raise low-density lipoprotein (LDL)-cholesterol levels, which in turn increase the risk of coronary heart disease (CHD). Several systematic reviews question whether reducing SFA intakes lowers CHD risk. Arguing to revise SFA recommendations, Philippe Legrand noted that SFA are heterogeneous in structure and function, are synthesized de novo by humans and only certain SFA in excess have been linked to CHD risk. We cannot consider all SFA as a block. The effects of reducing SFA intakes depend on which nutrients replace them and on which biomarkers or endpoints are assessed, Ronald Mensink observed. The effects of reducing SFA on $\mathrm{CHD}$ risk vary with the nutrient of comparison, whether carbohydrates, monounsaturated or polyunsaturated fatty acids. Substitution of SFA with polyunsaturated fatty acids was associated with a lower incidence of cardiovascular disease, while the effects of substitution with monounsaturated fatty acids or high-glycemic index carbohydrates are less clear.
\end{abstract}

(c) 2015 S. Karger AG, Basel

\begin{tabular}{ll}
\hline KARGER 125/30 & $\begin{array}{l}\text { ( 2015 S. Karger AG, Basel } \\
0250-6807 / 15 / 0663-0104 \$ 39.50 / 0 \quad \text { Karger }\end{array}$ \\
$\begin{array}{l}\text { E-Mail karger@karger.com } \\
\text { www.karger.com/anm }\end{array}$ & $\begin{array}{l}\text { This is an Open Access article licensed under the terms of the } \\
\text { Creative Commons Attribution-NonCommercial 3.0 Un- } \\
\text { ported license (CC BY-NC) (www.karger.com/OA-license), } \\
\text { applicable to the online version of the article only. Distribu- } \\
\text { tion permitted for non-commercial purposes only. }\end{array}$
\end{tabular}

Two European experts on dietary fat and health debated the evidence for and against changing current dietary recommendations on saturated fat (SFA) intake at the biennial congress of the International Society for the Study of Fatty Acids and Lipids (ISSFAL), Stockholm, Sweden, June 29, 2014. The forum was held under the auspices of the International Union of Nutritional Sciences (IUNS) and the International Expert Movement to Improve Dietary Fat Quality (IEM, www.theiem.org).

Dietary advice to limit the consumption of saturated fatty acids (SFA) appeared as early as 1961 according to an American Heart Association report [1]. The rationale was based on evidence that high intakes of SFA raise serum cholesterol levels [2], which in turn increase the risk of atherosclerosis and coronary heart disease (CHD) [3]. However, the effectiveness of reducing SFA intakes in lowering the risk of CHD [4-6] has been called into question by weaknesses in the data $[7,8]$, the complexity of CHD [9], multiplicity of risk factors for the disease (e.g., genetics, smoking, age, sex, obesity, diabetes, hypertension, hyperlipidemia, physical inactivity, etc.), the inadequacy of a single biomarker to assess disease risk [10], certain reports and several systemic reviews $[11,12]$ that some SFA do not raise cholesterol levels [13]. Others have defended limits or reductions in SFA consumption [14, 15]. In 2008, the Joint Expert Consultation on Fats and Fatty Acids in Human Nutrition of the Food and Agriculture Organization and the World Health Organization concluded that convincing evidence supported partially

Joyce A. Nettleton

ScienceVoice Consulting

2931 Race Street

Denver, CO 80205 (USA)

E-Mail sciencevoice1@gmail.com 
replacing dietary SFA with PUFA for reducing the risk of CHD [16]. Similarly, several systematic reviews concluded that the partial replacement of SFA with PUFA decreased the risk of CHD, especially in men [17-19]. Together, these and other studies have rekindled arguments about the appropriate recommendations for SFA intakes in $\mathrm{CHD}$ risk reduction.

Urging that the time for new recommendations had arrived, Philippe Legrand, of the French National Institute for Agricultural Research, Rennes, France, emphasized that 'SFA are nutrients, not poisons'. They supply energy and some have specific physiological functions, for example, cell signaling [20] and protein-fatty acid acylation [21]. They are heterogeneous in structure and function [22] and humans can synthesize them de novo. There are important metabolic differences between various SFA [23]. For example, some SFA such as myristic acid are not stored, but are rapidly oxidized or converted to palmitic acid, which is stored [24]. Stearic acid, an 18-carbon SFA, is readily desaturated to oleic acid [25]. Besides supplying energy, some SFA have other important physiological effects as suggested by in vitro studies, for instance, suppression of colonic inflammation [26] and the regulation of apoptosis in cancer cells [27]. Certain SFA are also structural components of sphingolipids and ceramides, which are important components of cell membranes, skin and myelin. Thus, viewing all SFA as a single dietary block ignores the different effects of individual SFA. If anything, dietary advice should focus on SFA with 12 to 16 carbons, which, in excess, have been associated with increased CHD risk in some studies [2830]. This focus is reflected in the updated nutritional recommendations in France, which distinguish between the consumption of total SFA at a maximum of $12 \%$ energy and intakes of lauric, myristic and palmitic acids, which are limited to no more than $8 \%$ energy [31].

Professor Legrand concluded his presentation by drawing attention to the apparent inadequacy of the 'classical' risk markers to characterize saturates in terms of cardiovascular risk. Lauric acid strongly reduces the total-to-HDL-cholesterol ratio (TC:HDL-C), considered the most reliable predictor of heart disease [32], largely by increasing HDL-C levels [33]. Based on this indicator, lauric acid could be considered a heart-healthy saturate.

Mensink questioned the drive to change dietary SFA recommendations. He noted that several reviews [11,34] concluded that the effect of lower SFA intakes on the risk of CHD depends on which nutrients replace them [35]. There is scientific evidence that a mixture of SFA increases LDL-cholesterol (LDL-C) compared with carbohy- drates and unsaturated fatty acids [36] and that LDL-C is a risk factor for CHD. The question is, why are SFA intakes so weakly linked to CHD? Some explanation may relate to the inaccuracy and variability of dietary intake data and of SFA in particular. Confounding variables and the multifactorial nature of CHD risk also complicate the interpretation of existing data [37]. Presently, data are insufficient to establish a causal relationship between SFA and CHD. Sometimes, observational studies complement randomized trial data, but these two types of studies can also provide conflicting evidence. This discordance has been shown in CHD or cardiovascular disease studies on antioxidants, folic acid (homocysteine) and SFA.

Assessments of the effects of SFA on CHD risk depend in part on which biomarkers or endpoints are assessed: levels of plasma LDL-C, TC:HDL-C ratio or changes in HDL-C. These responses vary with the nutrient of comparison, whether it is carbohydrate, monounsaturated (MUFA) or polyunsaturated fatty acids (PUFA). TC:HDL-C is more sensitive and specific than either TC or LDL-C $[33,38]$, but the effects of dietary fats on TC:HDL-C may differ markedly from their effects on LDL-C. Mensink noted that we do not know what the best combination of lipid biomarkers is and we know little about the effects of SFA on other CHD-related risks.

The discussion shifted to the type of macronutrients that might replace dietary SFA if their intake is reduced $[35,39]$. While there is abundant evidence that replacing SFA with PUFA reduces CHD risk [18], there is growing evidence that increased intake of highly refined carbohydrates - those with a high glycemic index - may be associated with a greater CHD risk [40-43]. Others reported that replacing SFA with carbohydrates has little or no effect on CHD [44] or mortality [17]. Diets high in carbohydrates have been associated with lipogenesis [45] and higher plasma levels of triglycerides, small, dense LDL particles, and lower levels of HDL particles [46] in plasma. It is of particular concern that carbohydrate-rich diets with a high glycemic index resulted in LDL particles of smaller size, which are more atherogenic, even in individuals at low-risk of CHD [47-49]. Plasma lipoprotein responses to dietary carbohydrate were also associated with an individual's genetically determined lipoprotein profile [50].

In contrast to the findings on high-carbohydrates in low-SFA diets, substitution of SFA with PUFA was associated with a lower incidence of cardiovascular disease [17]. Early trials of diets relatively low in SFA but high in vegetable PUFA reported significantly lower rates of 
myocardial infarction, sudden death and cerebral infarction in men, but overall mortality was not always changed $[51,52]$. Two other trials reported nonsignificant effects on cardiovascular disease of replacing SFA with PUFA $[53,54]$. However, these early trials have been criticized because both SFA and trans fatty acid intakes were partially replaced with unsaturated fats that included both n-6 and n-3 PUFAs, which may affect CHD risk differently $[55,56]$.

Time constraints did not permit the speakers to focus on total dietary patterns, although both recognized that several dietary patterns have been associated with lower CHD risk and events, LDL-cholesterol levels and blood pressure [57-59]. In particular, a Mediterranean-type diet has been most frequently associated with improved CHD risk, fewer CHD events, fewer coronary complications and improved survival, even though no uniform definition of this dietary pattern has been agreed [60-62].

In discussion with the audience, Joseph Hibbeln, $\mathrm{Na}$ tional Institutes of Health, USA, questioned Mensink's suggestion that dietary recommendations should be 'conservative,' asking whether that means resistant to change or cautious interpretation? To continue the status quo recommendations, which were established in the 1970s, would be considered conservative. However, there is a paucity of substantial causal and associative data from the last 50 years to support these recommendations. Mensink commented that recommendations should be preventive and given the debate about SFA and CHD, one should wait for greater certainty before changing the recommendations.

William Lands, retired professor, asserted that talking about the predictive ability of LDL-C closely suggests causality, which is not evidence-based. LDL-C appears in the blood stream as a result of VLDL hydrolysis, which is accompanied by the release of huge quantities of nonesterified fatty acids [63]. That is the major concern, not LDL-C. Lotte Lauritzen, University of Copenhagen, Denmark, also challenged the focus on LDL-C, noting that the metabolic syndrome (MetS) is another marker for CHD and lifestyle diseases. The effects of SFA on markers of MetS may be quite different from those on LDL-C [64].

Mensink agreed that the focus should extend beyond LDL-C, but because the effects of SFA on other markers are not well known, it is too early to consider different SFA separately. We need to consider the entire evidence base, determine what is certain, what is less certain and what we do not know. Then we would have the basis to derive new evidence-based guidelines.
Chris Ramsden, National Institutes of Health, USA, noted the possibility of substantial publication bias in several earlier clinical trials that might not have occurred under current standards for clinical trial protocols. Concerns relate to confounding variables, failure to distinguish between n-3 and n- 6 fatty acids and inadequate study design [55]. LDL is a complex molecule in which the core is esterified mainly to linoleic acid. Many oxidized linoleic acid products are major components of atherosclerotic plaque, as observed in smokers and those consuming oxidized vegetable oils [65]. Could potentially oxidized linoleic acid and other fatty acid products help account for the relationship between LDL and heart disease? Legrand suggested that the problem could occur in the case of excess linoleic acid, but we do not know how much is excess.

Susan Carlson, University of Kansas Medical Center in the United States, wondered what balance marker we are striving for. Is it more or less SFA, the 10-10-10 percents [of saturated monounsaturated and polyunsaturated fatty acids]? The real issue is balance in the diet and the [scientific] justification for it. In his reply, Legrand referred to the new French dietary recommendations, which advise an intake of no more than $12 \%$ energy intake from all SFA, with the consumption of lauric, myristic and palmitic acids combined limited to $8 \%$ energy or less [31].

Jagdave Bhullar, Protherapix, Malaysia, pointed out the paradox that in Thailand, people consume mainly coconut oil, which is $98 \%$ SFA, yet they have the third lowest incidence of heart disease in Southeast Asia [66]. Similarly in Kerala, India, and Sri Lanka, almost every food is based on coconut milk or coconut oil and rates of CHD are low [67]. Mensink commented that heart disease cannot be explained only in terms of SFA - there is much more to it than SFA. Some evidence suggests that virgin coconut oil diets in humans do not raise the TC:HDL-C ratio compared with olive or palm oil [68].

Andrew Sinclair, Deakin University, Australia, drew attention to the fact that in many nutritional debates there is a lack of scientific rigor in what is put forward. Discussants often just give opinions, not comments based on sound facts. The focus should be on well-defined issues.

In conclusion, Mensink noted three main needs: first, consideration of the other factors related to CHD, for example, systemic inflammation, blood pressure and endothelial function, because LDL-C is not the only risk factor; second, the determination of what should best replace SFA in the diet; and third, thinking in terms of foods and 
dietary patterns rather than nutrients. Legrand concluded that it may be time to revisit the relationships between epidemiology and physiology; to determine if there is excess intake and if so, evaluate what is the best replacement for those foods or nutrients; and finally, to avoid describing foods and nutrients as 'good' or 'bad'. All agreed that dietary recommendations should also be food-based.

\section{Disclosure Statement}

Financial assistance for this publication, travel funds to attend the ISSFAL meeting and honoraria were provided to the authors or their institutions from an unrestricted educational grant from Unilever NV, under the auspices of the International Union of Nutritional Sciences and the International Expert Movement to Improve Dietary Fat Quality (IEM, www.theiem.org).

\section{References}

1 American Heart Association: Dietary fat and its relation to heart attacks and strokes. Report by the Central Committee for Medical and Community Program of the American Heart Association. JAMA 1961;175:389-391.

-2 Keys A, Anderson JT, Grande F: Prediction of serum-cholesterol responses of man to changes in fats in the diet. Lancet 1957;273: 959-966.

-3 Kannel WB, Dawber TR, Kagan A, Revotskie $\mathrm{N}$, Stokes J 3rd: Factors of risk in the development of coronary heart disease-six year follow-up experience. The Framingham Study. Ann Intern Med 1961;55:33-50.

4 Ravnskov U: The questionable role of saturated and polyunsaturated fatty acids in cardiovascular disease. J Clin Epidemiol 1998;51: 443-460.

5 Taubes G: Nutrition. The soft science of dietary fat. Science 2001;291:2536-2545.

-6 Sanders TA: Reappraisal of SFA and cardiovascular risk. Proc Nutr Soc 2013;72:390-398.

7 Lawrence GD: Dietary fats and health: dietary recommendations in the context of scientific evidence. Adv Nutr 2013;4:294-302.

8 German JB, Dillard CJ: Saturated fats: what dietary intake? Am J Clin Nutr 2004;80:550559.

-9 Libby P: Changing concepts of atherogenesis. J Intern Med 2000;247:349-358.

-10 Institute of Medicine: Evaluation of Biomarkers and Surrogate Endpoints in Chronic Disease. Washington, DC, The National Academies Press, 2010.

11 Siri-Tarino PW, Sun Q, Hu FB, Krauss RM: Meta-analysis of prospective cohort studies evaluating the association of saturated fat with cardiovascular disease. Am J Clin Nutr 2010;91:535-546.

12 Skeaff CM, Miller J: Dietary fat and coronary heart disease: summary of evidence from prospective cohort and randomised controlled trials. Ann Nutr Metab 2009;55:173-201.

13 Mensink RP: Effects of stearic acid on plasma lipid and lipoproteins in humans. Lipids 2005; 40:1201-1205.

14 Stamler J: Diet-heart: a problematic revisit. Am J Clin Nutr 2010;91:497-499.

-15 Pedersen JI, James PT, Brouwer IA, Clarke R, Elmadfa I, Katan MB, Kris-Etherton PM, Kromhout D, Margetts BM, Mensink RP, Norum KR, Rayner M, Uusitupa M: The im- portance of reducing SFA to limit CHD. Br J Nutr 2011;106:961-963.

16 Joint FAO/WHO Expert Consultation on Fats and Fatty Acids in Human Nutrition: Interim Summary of Conclusions and Dietary Recommendations on Total Fat and Fatty Acids. Geneva, World Health Organization, 2008, pp 1-12.

17 Jakobsen MU, O'Reilly EJ, Heitmann BL, Pereira MA, Balter K, Fraser GE, Goldbourt U, Hallmans G, Knekt P, Liu S, Pietinen P, Spiegelman D, Stevens J, Virtamo J, Willett WC, Ascherio A: Major types of dietary fat and risk of coronary heart disease: a pooled analysis of 11 cohort studies. Am J Clin Nutr 2009;89:1425-1432.

18 Mozaffarian D, Micha R, Wallace S: Effects on coronary heart disease of increasing polyunsaturated fat in place of saturated fat: a systematic review and meta-analysis of randomized controlled trials. PLoS Med 2010;7:e1000252.

19 Schwab U, Lauritzen L, Tholstrup T, Haldorssoni T, Riserus U, Uusitupa M, Becker W: Effect of the amount and type of dietary fat on cardiometabolic risk factors and risk of developing type 2 diabetes, cardiovascular diseases, and cancer: a systematic review. Food Nutr Res 2014;58:25145.

20 Tan J, McKenzie C, Potamitis M, Thorburn AN, Mackay CR, Macia L: The role of shortchain fatty acids in health and disease. Adv Immunol 2014;121:91-119.

21 Towler DA, Gordon JI, Adams SP, Glaser L: The biology and enzymology of eukaryotic protein acylation. Annu Rev Biochem 1988;57:69-99.

22 Hughes TA, Heimberg M, Wang X, Wilcox H, Hughes SM, Tolley EA, Desiderio DM, Dalton JT: Comparative lipoprotein metabolism of myristate, palmitate, and stearate in normolipidemic men. Metabolism 1996;45:1108-1118.

23 Legrand P, Rioux V: The complex and important cellular and metabolic functions of saturated fatty acids. Lipids 2010;45:941-946.

24 Shadid S, Koutsari C, Jensen MD: Direct free fatty acid uptake into human adipocytes in vivo: relation to body fat distribution. Diabetes 2007;56:1369-1375.

25 Rhee SK, Kayani AJ, Ciszek A, Brenna JT: Desaturation and interconversion of dietary stearic and palmitic acids in human plasma and lipoproteins. Am J Clin Nutr 1997;65: 451-458.
26 Zimmerman MA, Singh N, Martin PM, Thangaraju M, Ganapathy V, Waller JL, Shi H, Robertson KD, Munn DH, Liu K: Butyrate suppresses colonic inflammation through HDAC1-dependent Fas upregulation and Fas-mediated apoptosis of T cells. Am J PhysiolGastrointest Liver Physiol2012;302:G1405G1415.

27 Hofmanova J, Strakova N, Vaculova AH, Tylichova Z, Safarikova B, Skender B, Kozubik A: Interaction of dietary fatty acids with tumour necrosis factor family cytokines during colon inflammation and cancer. Mediators Inflamm 2014;2014:848632.

28 Yamagishi K, Nettleton JA, Folsom AR; ARIC Study Investigators: Plasma fatty acid composition and incident heart failure in middleaged adults: the Atherosclerosis Risk in Communities (ARIC) Study. Am Heart J 2008;156: 965-974.

29 Lemaitre RN, King IB, Sotoodehnia N, Knopp RH, Mozaffarian D, McKnight B, Rea TD, Rice K, Friedlander Y, Lumley TS, Raghunathan TE, Copass MK, Siscovick DS: Endogenous red blood cell membrane fatty acids and sudden cardiac arrest. Metabolism 2010;59: 1029-1034.

30 Kabagambe EK, Baylin A, Siles X, Campos H: Individual saturated fatty acids and nonfatal acute myocardial infarction in Costa Rica. Eur J Clin Nutr 2003;57:1447-1457.

31 Legrand P, Morise A, Kalonji E: Update of French Nutritional Recommendations for Fatty Acids; in Simopoulos AP (ed): Healthy Agriculture, Healthy Nutrition, Healthy People. Basel, Karger, 2011, pp 137-143.

32 Kinosian B, Glick H, Preiss L, Puder KL: Cholesterol and coronary heart disease: predicting risks in men by changes in levels and ratios. J Investig Med 1995;43:443-450.

33 Mensink RP, Zock PL, Kester AD, Katan MB: Effects of dietary fatty acids and carbohydrates on the ratio of serum total to HDL cholesterol and on serum lipids and apolipoproteins: a meta-analysis of 60 controlled trials. Am J Clin Nutr 2003;77:11461155.

34 Mente A, de Koning L, Shannon HS, Anand SS: A systematic review of the evidence supporting a causal link between dietary factors and coronary heart disease. Arch Intern Med 2009;169:659-669. 
35 Micha R, Mozaffarian D: Saturated fat and cardiometabolic risk factors, coronary heart disease, stroke, and diabetes: a fresh look at the evidence. Lipids 2010;45:893-905.

-36 Faghihnia N, Mangravite LM, Chiu S, Bergeron N, Krauss RM: Effects of dietary saturated fat on LDL subclasses and apolipoprotein CIII in men. Eur J Clin Nutr 2012;66: 1229-1233.

37 Mensink RP: Dietary Fatty acids and cardiovascular health - an ongoing controversy. Ann Nutr Metab 2011;58:66-67.

38 Natarajan S, Glick H, Criqui M, Horowitz D, Lipsitz SR, Kinosian B: Cholesterol measures to identify and treat individuals at risk for coronary heart disease. Am J Prev Med 2003;25: 50-57.

-39 Astrup A, Dyerberg J, Elwood P, Hermansen K, Hu FB, Jakobsen MU, Kok FJ, Krauss RM, Lecerf JM, LeGrand P, Nestel P, Riserus U, Sanders T, Sinclair A, Stender S, Tholstrup T, Willett WC: The role of reducing intakes of saturated fat in the prevention of cardiovascular disease: where does the evidence stand in 2010? Am J Clin Nutr 2011;93:684-688.

-40 Sonestedt E, Wirfalt E, Wallstrom P, Gullberg B, Drake I, Hlebowicz J, Nordin Fredrikson G, Hedblad B, Nilsson J, Krauss RM, Orho-Melander M: High disaccharide intake associates with atherogenic lipoprotein profile. Br J Nutr 2012;107:1062-1069.

-41 Jakobsen MU, Dethlefsen C, Joensen AM, Stegger J, Tjonneland A, Schmidt EB, Overvad $\mathrm{K}$ : Intake of carbohydrates compared with intake of saturated fatty acids and risk of myocardial infarction: importance of the glycemic index. Am J Clin Nutr 2010;91:1764-1768.

42 Estruch R, Ros E, Salas-Salvado J, Covas MI, Corella D, Aros F, Gomez-Gracia E, RuizGutierrez V, Fiol M, Lapetra J, LamuelaRaventos RM, Serra-Majem L, Pinto X, Basora J, Munoz MA, Sorli JV, Martinez JA, Martinez-Gonzalez MA, PREDIMED Study Investigators: Primary prevention of cardiovascular disease with a Mediterranean diet. N Engl J Med 2013;368:1279-1290.

43 Jakobsen MU, Overvad K: Macronutrient advice for ischemic heart disease prevention. Curr Opin Lipidol 2011;22:33-36.

-44 Howard BV, Van Horn L, Hsia J, Manson JE, Stefanick ML, Wassertheil-Smoller S, Kuller LH, LaCroix AZ, Langer RD, Lasser NL, Lewis CE, Limacher MC, Margolis KL, Mysiw WJ, Ockene JK, Parker LM, Perri MG, Phillips L, Prentice RL, Robbins J, Rossouw JE, Sarto GE, Schatz IJ, Snetselaar LG, Stevens VJ, Tinker LF, Trevisan M, Vitolins MZ, Anderson GL, Assaf AR, Bassford T, Beresford SA, Black HR, Brunner RL, Brzyski RG, Caan B, Chlebowski RT, Gass M, Granek I, Greenland P, Hays J, Heber D, Heiss G, Hendrix SL, Hubbell FA, Johnson KC, Kotchen JM: Lowfat dietary pattern and risk of cardiovascular disease: the Women's Health Initiative Randomized Controlled Dietary Modification Trial. JAMA 2006;295:655-666.
45 Parks EJ, Parks EJ: Changes in fat synthesis influenced by dietary macronutrient content. Proc Nutr Soc 2002;61:281-286.

46 Siri PW, Krauss RM: Influence of dietary carbohydrate and fat on LDL and HDL particle distributions. Curr Atheroscler Rep 2005;7: 455-459.

47 Gerber PA, Berneis K: Regulation of low-density lipoprotein subfractions by carbohydrates. Curr Opin Clin Nutr Metab Care 2012; 15:381-385.

48 Hoogeveen RC, Gaubatz JW, Sun W, Dodge RC, Crosby JR, Jiang J, Couper D, Virani SS, Kathiresan S, Boerwinkle E, Ballantyne CM: Small dense low-density lipoprotein-cholesterol concentrations predict risk for coronary heart disease: the Atherosclerosis Risk In Communities (ARIC) study. Arterioscler Thromb Vasc Biol 2014;34:1069-1077.

49 Krauss RM, Dreon DM: Low-density-lipoprotein subclasses and response to a low-fat diet in healthy men. Am J Clin Nutr 1995;62: 478S-487S.

50 Dreon DM, Fernstrom HA, Miller B, Krauss RM: Low-density lipoprotein subclass patterns and lipoprotein response to a reducedfat diet in men. FASEB J 1994;8:121-126.

51 Dayton S, Pearce ML, Goldman H, Harnish A, Plotkin D, Shickman M, Winfield M, Zager A, Dixon W: Controlled trial of a diet high in unsaturated fat for prevention of atherosclerotic complications. Lancet 1968;2:10601062.

52 Leren P: The Oslo diet-heart study. Elevenyear report. Circulation 1970;42:935-942.

53 Frantz ID Jr, Dawson EA, Ashman PL, Gatewood LC, Bartsch GE, Kuba K, Brewer ER: Test of effect of lipid lowering by diet on cardiovascular risk. The Minnesota Coronary Survey. Arteriosclerosis 1989;9:129-135.

54 Morris JN, Ball K, Antonis A: Controlled trial of soya-bean oil in myocardial infarction. Report of a research committee to the Medical Research Council. Lancet 1968;2:693-700.

55 Ramsden CE, Hibbeln JR, Majchrzak SF, Davis JM: $\mathrm{n}-6$ fatty acid-specific and mixed polyunsaturate dietary interventions have different effects on CHD risk: a meta-analysis of randomised controlled trials. Br J Nutr 2010; 104:1586-1600.

56 Ramsden CE, Zamora D, Leelarthaepin B, Majchrzak-Hong SF, Faurot KR, Suchindran CM, Ringel A, Davis JM, Hibbeln JR: Use of dietary linoleic acid for secondary prevention of coronary heart disease and death: evaluation of recovered data from the Sydney Diet Heart Study and updated meta-analysis. BMJ 2013;346:e8707.
57 Swain JF, McCarron PB, Hamilton EF, Sacks FM, Appel LJ: Characteristics of the diet patterns tested in the optimal macronutrient intake trial to prevent heart disease (OmniHeart): options for a heart-healthy diet. J Am Diet Assoc 2008;108:257-265.

58 Bertoia ML, Triche EW, Michaud DS, Baylin A, Hogan JW, Neuhouser ML, Tinker LF, Van Horn L, Waring ME, Li W, Shikany JM, Eaton CB: Mediterranean and Dietary Approaches to Stop Hypertension dietary patterns and risk of sudden cardiac death in postmenopausal women. Am J Clin Nutr 2014;99:344351.

59 Eckel RH, Jakicic JM, Ard JD, de Jesus JM, Houston Miller N, Hubbard VS, Lee IM, Lichtenstein AH, Loria CM, Millen BE, Nonas CA, Sacks FM, Smith SC Jr, Svetkey LP, Wadden TA, Yanovski SZ; American College of Cardiology/American Heart Association Task Force on Practice Guidelines: 2013 AHA/ACC guideline on lifestyle management to reduce cardiovascular risk: a report of the American College of Cardiology/American Heart Association Task Force on Practice Guidelines. J Am Coll Cardiol 2014;63:29602984.

60 Stradling C, Hamid M, Taheri S, Thomas GN: A review of dietary influences on cardiovascular health: part 2: dietary patterns. Cardiovasc Hematol Disord Drug Targets 2014;14: 50-63.

61 de Lorgeril M, Salen P: Mediterranean diet in secondary prevention of CHD. Public Health Nutr 2011;14:2333-2337.

62 Chiva-Blanch G, Badimon L, Estruch R: Latest evidence of the effects of the Mediterranean diet in prevention of cardiovascular disease. Curr Atheroscler Rep 2014;16:446.

63 Lands B: Historical perspectives on the impact of n-3 and n- 6 nutrients on health. Prog Lipid Res 2014;55:17-29.

64 Nettleton JA, Jebb S, Riserus U, Koletzko B, Fleming J: Role of dietary fats in the prevention and treatment of the metabolic syndrome. Ann Nutr Metab 2014;64:167-178.

65 Waddington E, Sienuarine K, Puddey I, Croft $\mathrm{K}$ : Identification and quantitation of unique fatty acid oxidation products in human atherosclerotic plaque using high-performance liquid chromatography. Anal Biochem 2001; 292:234-244

66 World Life Expectancy: World Health Rankings: Coronary Heart Disease, Age Standardized Death Rates; in Anonymous (ed): World Health Rankings, World Life Expectancy, 2011.

-67 Amarasiri WA, Dissanayake AS: Coconut fats. Ceylon Med J 2006;51:47-51.

68 Voon PT, Ng TK, Lee VK, Nesaretnam K: Diets high in palmitic acid (16:0), lauric and myristic acids $(12: 0+14: 0)$, or oleic acid (18:1) do not alter postprandial or fasting plasma homocysteine and inflammatory markers in healthy Malaysian adults. Am J Clin Nutr 2011;94:1451-1457. 